\title{
Accounting
}

\section{The impact of corporate governance mechanisms and IFRS on earning management in Saudi} Arabia

\author{
Abdulwahid A. Hashed ${ }^{a, b^{*}}$ and Faozi A. Almaqtari ${ }^{b}$
}

${ }^{a}$ Department of Accounting, College of Business Administration, Prince Sattam Bin Abdulaziz University, Saudi Arabia

${ }^{b}$ Department of Accounting, College of Commerce and Economic, Hodeidah University, Yemen

\section{H R O N I C L E}

Article history:

Received: April 28, 2020

Received in revised format:

July 302020

Accepted: September 25, 2020

Available online:

September 25, 2020

Keywords:

Corporate governance

mechanisms

IFRS adoption

Compliance with IFRS

Earning management

Financial reporting quality

Saudi GAAP

\section{A B S T R A C T}

\begin{abstract}
The current research seeks to assess the influence of corporate governance mechanisms and IFRS adoption on compliance with IFRS, earning management, and financial reporting quality (FRQ). A sample comprises 102 Saudi listed firms for the period spanning from 2014 up to 2019 was used. The study used descriptive statistics, correlation analysis and multivariate analysis to estimate the results. The results reveal that while board size, board meeting and foreign ownership had negative effects on compliance with IFRS, board and audit committee independence exhibited a positive effect. Further, the results demonstrate that there was a sign of earning management under IFRS when a performance magnitude was used. The results also indicate that board and audit committee size, audit committee meeting and managerial ownership had significant negative effects on financial reporting quality however, board and audit committee independence showed a significant positive effect. Importantly, the results found that FRQ under IFRS was better than Saudi GAAP. The present research provides practical implications for policy makers, stock market authority, and academicians. More regulatory and disclosure requirements have to be imposed and financial reporting supervisory board need to be formed. The present research provides a novel contribution to IFRS compliance, earning management, financial reporting quality and corporate governance literature. It has a unique contribution as it attempts to investigate this issue in the context of an emerging economy and a recent IFRS adopter; Saudi Arabia that has special country-specific characteristics. The study also provides an evidence by investigating earning management and financial reporting quality under both sets of accounting standards; IFRS and Saudi GAAP.
\end{abstract}

\section{Introduction}

The Saudi Capital Market Authority (SCMA) issued its corporate governance code entitled "Corporate Governance Regulations in the Kingdom of Saudi Arabia" in 2006 and was revised in 2009 (Altuwaijri \& Kalyanaraman, 2016; Ghabayen, 2012; Hill et al., 2015; Shehata, 2015). Recently, a revised CG regulation has taken place which has been effective from 2017. The Saudi Corporate Governance Regulations (SCGRs) were voluntary until the beginning of 2009. However, from 2010 it has become mandatory in terms of implementation and reporting for listed companies (Alzahrani, 2013). All listed companies are liable to implement the code on a comply/explain basis generally indicated as a 'comply or explain' policy (AlQahtani, 2014; Alzahrani, 2013; Hill et al., 2015; Shehata, 2015). The provisions of the SCGRs require all listed companies to report their adherence and compliance with these provisions and to disclose and justify for non- compliance (Alzahrani, 2013; Hill et al., 2015). In case of

* Corresponding author

E-mail address: aa.abdullah@psau.edu.sa (A. A. Hashed) 
non-compliance with the provisions of the code, listed companies must justify and report the non-compliance reasons to the SCMA (Shehata, 2015). With regards to accounting standards, in 1986, Saudi Arabia made a crucial move to issue its own national accounting and auditing standards that were primarily adopted from the U.S standards (Al-matari et al., 2012). "Saudi Organization for Certified Public Accountants (SOCPA)" is the successor of the Saudi Accounting Association (SAA) which was the body that responsible for developing accounting standards in Saudi Arabia. All Gulf countries except Saudi Arabia have adopted IFRS and made it mandatory for all companies to prepare their financial reports based on IFRS. For example, Oman has adopted IAS since 1996 and UAE since 1999. Both countries are following IFRS since IAS were replaced by IFRS in 2001 (Ramady, 2012, P. 180). However, in the case of KSA, SOCPA has released a project in 2013 to shift to IFRS. SOCPA has approved a plan by which listed firms other than financial institutions would be mandated to follow SOCPA's new standards that will be IFRS with some modifications "IFRS as adopted in Saudi Arabia" (PWC, 2014). SOCPA approved an IFRS convergence Plan, called the "SOCPA Project for Transition to International Accounting \& Auditing Standards" (Manduca, 2016). Under this plan, financial institutions are required to comply with IFRS as per SAMA requirements. All listed firms are required to comply with IFRS beginning from 2017; and other remaining firms are mandated to comply with IFRS by 2018. "IFRS in Saudi Arabia are similar to the standards issued by the IASB with possible modifications in three respects: adding more disclosure requirements, removing optional treatments; and amending the requirements that contradict Shariah or local law, taking in consideration level of technical and professional preparedness in the Kingdom" (PWC, 2014). The present study investigates the impact of CG mechanisms and IFRS adoption on compliance with IFRS, earning management and financial reporting quality. The study is of three-fold objectives and contributions. Firstly, it seeks to assess the impact of corporate governance mechanisms on compliance with IFRS. Second, the study attempts to investigate the effect of IFRS adoption on earning management and financial reporting quality. Finally, the study compares the impact of corporate governance mechanisms on earning management and financial reporting quality pre- and post-IFRS adoption. Accordingly, the present study has several contributions and implications. It assesses the level of compliance with IFRS mandatory requirements by Saudi companies. Further, it tries to understand the role of corporate governance in curbing earning management practices. In the same context, the study has a unique contribution as it attempts to compare the effect of corporate governance mechanisms on earning management and financial reporting quality under the two sets of accounting standards; IFRS and Saudi GAAP. The study also seeks to evaluate the effect of IFRS adoption and weather the introduction of IFRS in Saudi Arabia has achieved its desired aim of better financial reporting quality. Hence, the study provides valuable insights to regulators, analysts, stock markets, professionals and academicians in this issue. The study introduces empirical evidences related to window dressing in IFRS disclosures and the quality of financial reporting or earnings management and the role of corporate governance mechanisms in this issue in the context of an emerging country; Saudi Arabia. The remainder of the study is organized as follows: section 2 introduces literature review. Section 3 presents the research design and methodology. Section 4 estimates the results and, finally, section 5 presents the conclusions.

\section{Literature review}

\subsection{Board characteristics}

Several studies argue that larger board size leads to better monitoring as the board members are diversified, more experienced and more effective (Mambondiani, 2011; Brown et al., 2011; Akhtaruddin et al., 2009). However, some other studies argue that smaller boards are better in terms of communication and coordination (Abbott et al., 2004), better quality information and disclosure levels (Al-Shaer et al., 2017; Juhman, 2017; Al-Akra et al., 2010). Similarly, some studies indicate that board size is linked with IFRS compliance (Juhman, 2017; Al-Akra et al., 2010). Contradictory, Ba-Abbad and Wan- Hussin, (2011) argue that board size is not associated with compliance with IFRS. In the context of FRQ, different studies reported that board size is positively and significantly associated with FRQ (Góis, 2009; Farber, 2005; Ditropoulos \& Asteriou, 2010) which contradicts Chalaki et al. (2012) and Ahmed and Duellman (2006) who advocate that board size is insignificantly associated with FRQ. Concerning board independence, (Nelson et al., 2010; Owusu-Ansah \& Yeoh, 2005; Samaha et al., 2012) reported that greater board independence is significantly linked with more comprehensive statutory disclosures, reduce the information asymmetry (Botti et al., 2013) and positively associated with FRQ (Bradbury et al., 2006; Koh et al., 2007; Ahmed \& Duellman; 2006). Contradictory, some studies (e.g., Cornett et al., 2009; Onuorah et al., 2016) indicate that board independence has a negative relationship with FRQ. However, Petra (2007) reported insignificant association between both. Nemours studies (e.g., Chou et al., 2013; Al-Ghamdi, 2012; Francis et al., 2012; Ntim \& Osei, 2011; Habbash, 2010, Modum et al. 2013; Bathula, 2008; García Lara et al., 2009; Chobpichien et al., 2008) indicate that frequency board meetings are essential for protection of shareholders' interests. They also argue that better board diligence is negatively and significantly linked with earnings management, leads to better disclosure levels. Contradictory, Habbash (2010) reported that meetings frequency may not deter earnings management practices.

\subsection{Audit committee attributes}

Different studies found that larger audit committee size is significantly and positively linked with FRQ (Al-Ghamdi, 2012), is negatively associated with earnings management (Cornett et al., 2008; Lin \& Hwang, 2010), and is positively related to 
voluntary disclosure (Akhtaruddin et al., 2009). Differently, it was found that audit committee size has an insignificant effect on earnings management (Baxter \& Cotter, 2009) and FRQ (Abbott et al., 2004). On the other hand, several studies indicated that board independence is positively and significantly linked with voluntary disclosure levels (Akhtaruddin et al., 2009; Akhtaruddin \& Haron, 2010; Mohamad \& Sulong, 2010; Abeysekera, 2010; Yuen et al., 2009), and reduces earnings management (Klein, 2002). Conversely, Lin et al. (2006) and Siregar and Utama (2008) reported that there is no significant association between audit committee independence and reduced earnings management. Further, Ruth et al. (2011) found an insignificant relationship between voluntary disclosures and audit committee independence. Song and Windram (2004) state that the frequency of audit committee meetings increases FRQ and Abbott et al. (2004) reported that it contributes to better IFRS disclosures. Similarly, Ebrahim (2007) advocates that it is associated with a lower incidence of earnings management. Differently, Baxter and Cotter (2009) reveal an insignificant association between the frequency of audit committee meetings and mitigating of earnings management or FRQ.

\subsection{Ownership structure}

Al-bassam et al. (2018) reported that voluntary disclosure is significantly associated with ownership structure. In the same context, Hambreg et al. (2013), Gordon et al (2012) and Silva et al. (2012) indicated that there is a positive relationship between IFRS adoption and foreign ownership. Likewise, Yasser et al. (2016) found a positive link between financial disclosure and foreign ownership. Further, several studies report that foreign ownership contributes to better FRQ (Lee et al., 2013; Srithanpong, 2013), and enhances the comparability of IFRS financial statements (DeFond et al., 2011). Further, Lee et al. (2013) and Srithanpong (2013) provided evidences from China and Thailand that there is a significant and positive association between the greater foreign ownership and FRQ under IFRS.

\subsection{Audit quality}

Street and Gray (2002) and Karim and Ahmed (2005) advocate that there is a positive association between greater IFRS compliance levels and a firm that audited by a Big-Four. Consistently, Onuorah et al. (2016) argue that FRQ is positively and significantly influenced by quality of external audit. However, Davidson et al. (2005) reported that earnings management is not reduced by the presence of a Big 5 auditor. Overall, several prior studies have investigated corporate governance in Saudi Arabia. However, there is a wide variation amongst prior studies of corporate governance in Saudi Arabia (Almaqtari et al., 2020). Majority of prior literature of corporate governance in Saudi Arabia discuss firm performance or disclosure issues (e.g., Alajlan, 2015; Rahman \& Omar, 2013; Al-Janadi et al., 2016; Al-bassam et al., 2015; Darweesh, 2015; Alzahrani, 2014; Alkahtani, 2013; Al-matari \& Al-Matari 2012; Ghabayen 2012). Importantly, these studies have been conducted in the context of Saudi GAAP. However, recently, Saudi Arabia has adopted IFRS for its financial reporting practices. Accordingly, an investigation of IFRS disclosures, earning management and financial reporting quality under the new set of accounting standards is necessary. Further, comparing earning management practices and financial reporting quality under IFRS and Saudi GAAP becomes important as prior studies in this context are limited to the local set of accounting standards. On the other hand, different studies also have been conducted in Saudi Arabia about earning management. For example, Alghamdi (2012) and Habbash and Alghamdi (2015) examined earning management in Saudi companies and reported that the four main incentives for Saudi managers to manage earnings are to increase the amount of remuneration to report a reasonable profit and avoid loss, to obtain a bank loan and to increase share price. Al-Thuneibat et al. (2016) reported that the effect of corporate governance on earnings management is statistically insignificant. They concluded that there is a big question mark on the effectiveness of corporate governance in Saudi Arabia. They also revealed that there is a high degree of compliance with corporate governance requirements, but there is no significant effect on earnings management. In the same context, Alshetwi (2016) found that audit committee members' multiple directorships have statistically insignificant relationship in reduction the level of earnings management in 98 Saudi nonfinancial listed companies. However, Habbash (2019) found that board size and independence are negatively associated with earnings management at significant levels. In the same line, Baatour et al. (2017) provided evidence that earnings management practices increase with the number of multiple directorships. They stated that multiple directorships have a positive and significant effect on real earnings management in the Kingdom of Saudi Arabia. However, they found no significant impact of multiple directorships on accrual-based earnings management. Alsultan (2017) concluded that Big 4 firms have a role in curbing earnings management only in income-decreasing activities. However, Habbash and Alghamdi (2016) indicated that only auditor opinion indicates earnings management practice, they advocate that auditors are powerless in front of managerial opportunistic activities.

Oraby (2017) indicated that accounting accrual- based earnings management strategy is used to manipulate earnings downward but it is not of value relevance because it has no effects on share prices. On the other hand, real activities-based earnings management strategy is statistically significant and of value relevance and it is used to manipulate net income upward. Managers engage in real activities-based earnings management practices to increase net income but investors in Saudi capital market understand these practices and adjust for their decisions by reducing the value relevance of earnings when determining share prices. However, there is a lack of studies that investigate the impact corporate governance on earning management especially after IFRS adoption. The present study has a novel contribution which sought to assess the effect of corporate governance on 
earning management pre- and post-IFRS adoption. All prior studies conducted in Saudi Arabia are mainly focused of the effect of corporate governance on earning management but IFRS issue is still new to the Saudi research literature.

\section{The proposed study}

The present research uses a sample of 102 non-financial companies listed on the Saudi Stock Market (Tadawul) for the period from 2014 up to 2019. The research period covered by the current study is divided into pre and post IFRS adoption. While the period from 2014 up to 2016 was considered as pre-IFRS adoption, the period from 2017 to 2019 is treated as post-IFRS period. The research framework of the present study comprises four dimensions of corporate governance namely; board of defectors effectiveness (size, independence and meetings), audit committee effectiveness (size, independence and meetings), ownership (foreign, family and managerial ownership) and audit quality by Big-4. Further, the study included the effect of IFRS adoption as a dummy variable for both periods; pre and post-IFRS adoption (see table 1). All these variables are treated as independent variables which are regressed against the dependent variables; IFRS compliance, earning management and financial reporting quality. Fig. 1 illustrates the research framework of the current study:

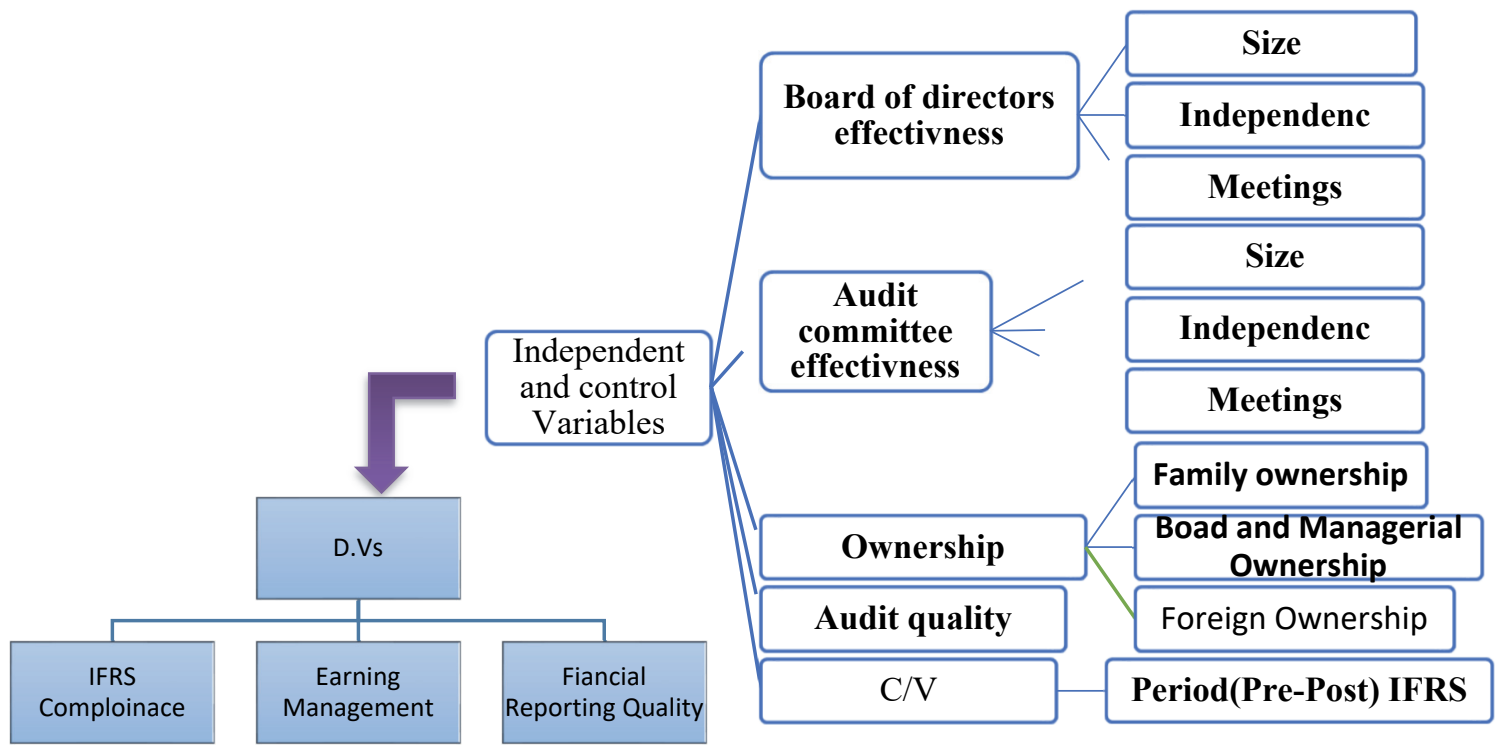

Fig. 1. Research framework

Table 1

Operational Definition of Variables

\begin{tabular}{|c|c|c|}
\hline Variables & Acronym & Description \\
\hline \multicolumn{3}{|r|}{ Dependent variables } \\
\hline Compliance with IFRS & IFRSC & $P C_{j}=\frac{\sum_{i=1} X_{i}}{R_{j}}$ \\
\hline Earning Management & Accrual (A) & $\begin{array}{l}\text { Discretionary accruals, Kothari et al. (2005) model as used by (Li et. al, 2018; Habbash \& Alghamdi, } \\
2016 \text { ) }\end{array}$ \\
\hline & Accrual (B) & Discretionary accruals, modified Jones model as used by (e.g., Alghamdi, 2012; Dong et al., 2020). \\
\hline $\begin{array}{l}\text { Financial Reporting quality } \\
\text { Independent Variables }\end{array}$ & FRQ & McNichols model (2002) \\
\hline Board Size & BSZE & "Total No. of the members of B.O.D" \\
\hline Board Independence & BIND & "No. of Independent board members / total No. of B.O.D" \\
\hline Board Meetings & BMET & Total No. of meetings attended by all board members/ total No. of meetings held during the year \\
\hline Audit Committee Size & ACSIZE & Total No. of the members of AC \\
\hline Audit Committee Independence & ACIND & No. of Independent AC members / total No. of AC members \\
\hline Audit Committee Meetings & ACDEL & Total No. of meetings attended by all AC members / total No. of meetings held during the year \\
\hline Audit quality & Big-4 & 1 if a firm audited by a Big-Four or 0 otherwise \\
\hline Family ownership & FMOWN & $\%$ of shares held by families \\
\hline Board/managerial ownership & MOWN & $\%$ of shares held by board members or management \\
\hline Foreign ownership & FOWN & $\%$ of shares held by foreign investors \\
\hline IFRS & IFRS & A dummy variable of 1 for post-IFRS adoption and 0 otherwise \\
\hline
\end{tabular}

\section{a. Measuring Compliance with IFRS}

The current study uses a compliance index checklist which is adopted from IASB 2017 and the Deloitte (Big-Four) checklist that summarizes IFRS disclosure requirements issued on 30 April 2017. It comprises 256 mandatory items from 36 standards 
which has been compared with similar prior studies in IFRS mandatory disclosure and compliance. Further, the present study uses "Partial Compliance (PC)" method for calculating IFRS disclosures. The study followed Street \& Gray (2001) and AlShiab (2003) for weighting the compliance index. The formula for PC is as follows:

$$
P C_{j}=\frac{\sum_{i=1} X_{i}}{R_{j}}
$$

$\mathrm{PCj}$ indicates the score of total compliance for an individual company and $0 \leq P C_{j} \leq 1$. Xi refers to the compliance level with mandatory disclosures of an individual accounting standard. Subsequently, the aggregate of the yielded compliance scores (X) has to be scaled by the aggregate number of the applicable standards for the respective company $\mathrm{j}$ i.e. $R_{j}$.

\section{b. Measuring Earning Management}

The most commonly used method by prior research to estimate earning management is modified Jones model (Dechow et al., 1995). However, Habbash and Alghamdi (2016) used a lagged return on assets as a performance magnitude that recommended by Kothari et al. (2005) to control the heteroscedasticity and misspecification problems. Accordingly, prior studies measure earning management used the modified Jones model with a performance magnitude (e.g., Li et. al, 2018; Habbash \& Alghamdi, 2016)or without a performance measure (e.g., Alghamdi, 2012; Dong et. al, 2020). Following these studies, the present study uses both a performance and without performance magnitude to estimate earning management. In this regard, Habbash \& Alghamdi (2016) described five steps to reach to the proxy for earnings management which are as follows:

1- Estimating total accruals $T A C C R U A L_{j, t}$ for a firm $\mathrm{j}$ in a year $\mathrm{t}$ by the difference between operating earnings $E A R N_{j, t}$ for a firm $\mathrm{j}$ in a year $\mathrm{t}$ and net cash flow from operations $C F O_{j, t}$ for firm $\mathrm{j}$ in a year $\mathrm{t}$.

$$
\operatorname{TACCRUAL}_{j, t}=E A R N_{j, t}-C F O_{j, t}
$$

2- Estimating the industry sectors' magnitude separately for each year as follows:

$$
\frac{T A C C R U A L_{j, t}}{A_{j, t-1}}=\alpha_{0}+\alpha_{1} \frac{1}{A_{j, t-1}}+\alpha_{2} \frac{\Delta S A L E_{j, t}-\Delta R E C_{j, t}}{A_{j, t-1}}+\alpha_{3} \frac{P P E_{j, t}}{A_{j, t-1}}+\alpha_{4} R O A_{j, t-1}+\varepsilon_{j, t}
$$

where $T A C C R U A L_{j, t}$ denotes the total accruals for a firm $\mathrm{j}$ in a year $\mathrm{t}, A_{j, t-1}$ is the total assets a firm $\mathrm{j}$ in a year $\mathrm{t}-1, \triangle S A L E_{j, t}$ is the change in revenues for a firm $\mathrm{j}$ in a year $\mathrm{t}, \triangle R E C_{j, t}$ is the change in accounts receivables fro a firm $\mathrm{j}$ in a year $\mathrm{t}, P P E_{j, t}$ is property, plant and equipment for a firm $\mathrm{j}$ in a year $\mathrm{t}, R O A_{j, t-1}$ is the return on assets for a firm $\mathrm{j}$ in a year $\mathrm{t}$, and $\varepsilon_{j, t}$ is the residuals.

3- Calculation of non-discretionary accruals $N D A C C R U A L_{j, t}$ adding coefficients $\left(\alpha_{0}, \alpha_{1}, \alpha_{2}, \alpha_{3}\right.$ and $\left.\alpha_{4}\right)$ for every industry in the previous Eq. (3):

$$
N D A C C R U A L_{j, t}=\alpha_{0}+\alpha_{1} \frac{1}{A_{j, t-1}}+\alpha_{2} \frac{\Delta S A L E_{j, t}-\Delta R E C_{j, t}}{A_{j, t-1}}+\alpha_{3} \frac{P P E_{j, t}}{A_{j, t-1}}+\alpha_{4} R O A_{j, t-1}
$$

4- Determining the difference between total accruals $T A C C R U A L_{j, t}$ and non-discretionary accruals $N D A C C R U A L_{j, t}$ :

$$
\begin{aligned}
& \operatorname{DACCRUAL_{j,t}}=\operatorname{TACCRUAL}_{j, t}-N D A C C R U A L_{j, t} \\
& A D A C C R U A L_{j, t}=\left|D A C C R U A L_{j, t}\right|
\end{aligned}
$$

\section{c. Measuring Financial Reporting Quality}

There are several measure of financial reporting quality. For example, Al-Shaer et al (2017) and Onuorah, et al. (2016) used Jones Model (1991), Li and Wang (2010) and Kardan et al. (2016) employed Dechow and Dichev model (2002), Call et al. (2017), and Gomariz and Ballesta (2013) employed McNichols model (2002), and Chalaki et. al. (2012) utilized Collins and Kothari model (1989) for measuring financial reporting quality. The current study uses McNichols (2002) model to measure FRQ. The model equation is as follows:

$$
\frac{T C A_{j, t}}{A S S E T_{j, t}}=\beta_{0 j}+\beta_{1, j}+\frac{C F O_{j, t-1}}{A S S E T_{j, t}}+\beta_{2 j} \frac{C F O_{j, t}}{A S S E T_{j, t}}+\beta_{3 j} \frac{C F O_{j, t+1}}{A S S E T_{j, t}}+\beta_{4 j} \frac{\Delta R E V_{j, t}}{A S S E T_{j, t}}+\beta_{5 j} \frac{P P E_{j, t}}{A S S E T_{j, t}}+\varepsilon_{j, t}
$$


where; $T C A_{j, t}$ is the total current accruals in year t of a firm $\mathrm{j}, C F O_{j, t}$ is the operating cash flows of the current period, $C F O_{j, t-1}$ is the operating cash flows of the previous period, $C F O_{j, t+1}$ is the operating cash flows of the next period, $\triangle R E V_{j, t}$ is the change in revenues, $P P E_{j, t}$ is the level of property, plant and equipment and $\varepsilon_{\mathrm{j}, \mathrm{t}}$ is the error term in year $\mathrm{t}$ for firm $\mathrm{j}$. All these variables are scaled by lagged total assets $\operatorname{ASSET}_{j, t}$.

\subsection{Model Specification}

The present study is of three-fold objectives; it seeks to assess the impact of corporate governance mechanisms on 1) IFRS compliance, 2) earning management, and 3) financial reporting quality.

a) IFRS Compliance Model Specification

The following model is estimated to assess the effect of corporate governance mechanisms on IFRS compliance:

$$
\begin{gathered}
\operatorname{IFRSC}_{j t}=\beta_{0}+\beta_{1} \text { BSIZE }_{i t}+\beta_{2} \text { BIND }_{i t}+\beta_{3} B M E T_{i t}+\beta_{4} \text { ACSIZE }_{i t}+\beta_{5} \text { ACSIND }_{i t}+\beta_{6} A C M E T_{i t} \\
+\beta_{7} F M O W N_{i t}+\beta_{8} B E Q_{i t}+\beta_{9} A Q_{i t}+\varepsilon_{i t}
\end{gathered}
$$

Model 1

b) Earning Management Model Specification

The present study employs the following models to investigate the effect of corporate governance on earning management. Following is the description of these models:

$$
\begin{aligned}
& \operatorname{DACCRUAL}(A)_{j t}=\beta_{0}+\beta_{1} B S I Z E_{i t}+\beta_{2} B I N D_{i t}+\beta_{3} B M E T_{i t}+\beta_{4} A C S I Z E_{i t}+\beta_{5} A C S I N D_{i t}+ \\
& \beta_{6} A C M E T_{i t}+\beta_{7} F M O W N_{i t}+\beta_{8} B E Q_{i t}+\beta_{9} A Q_{i t}+\varepsilon_{i t} \\
& \operatorname{DACCRUAL}(B)_{j t}=\beta_{0}+\beta_{1} \text { BSIZE }_{i t}+\beta_{2} \text { BIND }_{i t}+\beta_{3} \text { BMET }_{i t}+\beta_{4} A_{C S I Z E_{i t}}+\beta_{5} A C S I N D_{i t}+ \\
& \beta_{6} A C M E T_{i t}+\beta_{7} F M O W N_{i t}+\beta_{8} B E Q_{i t}+\beta_{9} A Q_{i t}+\varepsilon_{i t}
\end{aligned}
$$

Model 2

Model 3

where $D A C C R U A L(A \text { and } B)_{j t}$ are the measures of earning management using a performance magnitude (A) and without a performance magnitude (B). After adding the effect of IFRS adoption as a dummy variable of "1" for IFRS standards and "0" for Saudi GAAP, the following models are used:

$$
\begin{aligned}
& \begin{aligned}
\text { DACCRUAL }(\text { Adummy })_{j t} \\
\quad=\beta_{0}+\beta_{1} \text { BSIZE }_{i t}+\beta_{2} B I N D_{i t}+\beta_{3} B M E T_{i t}+\beta_{4} A C S I Z E_{i t}+\beta_{5} A C S I N D_{i t} \\
+\beta_{6} A C M E T_{i t}+\beta_{7} F M O W N_{i t}+\beta_{8} B E Q_{i t}+\beta_{9} A Q_{i t}+\beta_{10} I F R S_{i t}+\varepsilon_{i t}
\end{aligned} \\
& \begin{array}{l}
\text { DACCRUAL }(\text { Bdummy })_{j t}=\beta_{0}+\beta_{1} B S I Z E_{i t}+\beta_{2} B I N D_{i t}+\beta_{3} B M E T_{i t}+\beta_{4} A C S I Z E_{i t}+ \\
\beta_{5} \text { ACSIND }_{i t}+\beta_{6} A C M E T_{i t}+\beta_{7} \text { FMOWN }_{i t}+\beta_{8} B E Q_{i t}+\beta_{9} A Q_{i t}+\beta_{10} I F R S_{i t}+\varepsilon_{i t}
\end{array}
\end{aligned}
$$

Model 4

The same models are also estimated individually for both IFRS and Saudi GAAP as follows:

$$
\begin{aligned}
& \text { DACCRUAL (Aifrs) })_{j t}=\beta_{0}+\beta_{1} \text { BSIZE }_{i t}+\beta_{2} \text { BIND }_{i t}+\beta_{3} B M E T_{i t}+\beta_{4} A C S I Z E_{i t}+\beta_{5} A C S I N D_{i t}+ \\
& \beta_{6} A C M E T_{i t}+\beta_{7} F M O W N_{i t}+\beta_{8} B E Q_{i t}+\beta_{9} A Q_{i t}+\varepsilon_{i t} \\
& D A C C R U A L(\text { Bifrs })_{j t} \\
& =\beta_{0}+\beta_{1} \text { BSIZE }_{i t}+\beta_{2} \text { BIND }_{i t}+\beta_{3} B M E T_{i t}+\beta_{4} A C S I Z E_{i t}+\beta_{5} \text { CCSIND }_{i t} \\
& +\beta_{6} A C M E T_{i t}+\beta_{7} F M O W N_{i t}+\beta_{8} B E Q_{i t}+\beta_{9} A Q_{i t}+\varepsilon_{i t} \\
& \text { DACCRUAL(AsGaap })_{j t} \\
& =\beta_{0}+\beta_{1} \text { BSIZE }_{i t}+\beta_{2} \text { BIND }_{i t}+\beta_{3} B M E T_{i t}+\beta_{4} A C S I Z E_{i t}+\beta_{5} \text { CCSIND }_{i t} \\
& +\beta_{6} A C M E T_{i t}+\beta_{7} F M O W N_{i t}+\beta_{8} B E Q_{i t}+\beta_{9} A Q_{i t}+\varepsilon_{i t} \\
& \text { DACCRUAL(BsGaap })_{j t} \\
& =\beta_{0}+\beta_{1} B S I Z E_{i t}+\beta_{2} \text { IIND }_{i t}+\beta_{3} B M E T_{i t}+\beta_{4} A C S I Z E_{i t}+\beta_{5} \text { ACSIND }_{i t} \\
& +\beta_{6} A C M E T_{i t}+\beta_{7} F M O W N_{i t}+\beta_{8} B E Q_{i t}+\beta_{9} A Q_{i t}+\varepsilon_{i t}
\end{aligned}
$$

Model 6

Model 7

Model 8 
The following models are estimated to investigate the impact of corporate governance mechanisms on FRQ:

$$
\begin{gathered}
F R Q_{j t}=\beta_{0}+\beta_{1} \text { BSIZE }_{i t}+\beta_{2} B I N D_{i t}+\beta_{3} B M E T_{i t}+\beta_{4} A C S I Z E_{i t}+\beta_{5} A C S I N D_{i t}+\beta_{6} A C M E T_{i t} \\
+\beta_{7} F M O W N_{i t}+\beta_{8} B E Q_{i t}+\beta_{9} A Q_{i t}+\varepsilon_{i t}
\end{gathered}
$$

Model 10

\section{Analysis and discussion}

\subsection{Descriptive statistics}

Table 2 presents descriptive statistics for the collective as well as pre and post-IFRS adoption models. Compliance with IFRS demonstrates that the minimum compliance is $64 \%$ with a maximum of $93 \%$ and an average compliance $78 \%$. The results show that accruals with a performance magnitude has a minimum value of $(0)$, maximum value of $(0.81)$ with a mean value of $(0.074)$ and standard deviation of (0.130) against a minimum value of (0), a maximum value of (0.741), an average of $(0.069)$ and standards deviation of (0.121). This is consistent with Habbash and Alghamdi (2016) who found that the minimum value of discretionary accrual is $(0.00)$ and the maximum value is $(0.78)$ with an average of $(0.10)$. The results also indicate that board size has an average of 8 members in the board with a minimum of 5 and a maximum of 12 members in the board. Further, the portion of independent members in the board has a mean of 4 members in the board with a minimum of 1 and a maximum of 8 members in the board. This indicates that approximately out of 12 members in the board there are 8 independent members. In the same context, board meetings have a minimum of 2 meetings in the year against 18 meetings in some companies with a mean of 5 meetings in the year.

Table 2

\begin{tabular}{|c|c|c|c|c|c|}
\hline \multirow[b]{2}{*}{ Variables } & & Mean & Maximum & Minimum & Std. Dev. \\
\hline & \multicolumn{5}{|c|}{ Collective Model: Obs.604 } \\
\hline IFRC & & 0.78 & 0.93 & 0.64 & 0.05 \\
\hline ACCRUAL & & 0.00 & 1.70 & -2.97 & 0.25 \\
\hline ACCRUAL(A) & & 0.074 & 0.811 & 0.00 & 0.130 \\
\hline ACCRUAL(B) & & 0.069 & 0.741 & 0.00 & 0.121 \\
\hline BSIZE & & 8.26 & 12.00 & 5.00 & 1.44 \\
\hline BIND & & 3.96 & 8.00 & 1.00 & 1.30 \\
\hline BMET & & 5.42 & 18.00 & 2.00 & 2.15 \\
\hline ACSIZE & & 3.54 & 7.00 & 3.00 & 0.75 \\
\hline ACIND & & 1.71 & 4.00 & 1.00 & 0.74 \\
\hline ACMET & & 5.42 & 17.00 & 1.00 & 1.91 \\
\hline FMOWN & & 0.019 & 0.825 & 0.000 & 0.084 \\
\hline BEQT & & 0.067 & 0.859 & 0.000 & 0.129 \\
\hline $\mathrm{AQ}$ & & 0.69 & 1.00 & 0.00 & 0.46 \\
\hline IFRS & & 0.50 & 1.00 & 0.00 & 0.50 \\
\hline Variables & \multicolumn{4}{|c|}{ Pre-IFRS Adoption Model: } & \\
\hline ACCRUAL(A) & 0.042 & & 0.811 & 0.00 & 0.101 \\
\hline ACCRUAL(B) & 0.039 & & 0.720 & 0.00 & 0.082 \\
\hline BSIZE & 8.17 & & 12.00 & 5.00 & 1.39 \\
\hline BIND & 3.88 & & 8.00 & 1.00 & 1.25 \\
\hline BMET & 5.39 & & 18.00 & 2.00 & 2.27 \\
\hline ACSIZE & 3.55 & & 7.00 & 3.00 & 0.77 \\
\hline ACIND & 1.66 & & 4.00 & 1.00 & 0.75 \\
\hline ACMET & 5.56 & & 17.00 & 1.00 & 2.05 \\
\hline FMOWN & 0.036 & & 0.825 & 0.000 & 0.119 \\
\hline BEQT & 0.065 & & 0.603 & 0.000 & 0.119 \\
\hline $\mathrm{AQ}$ & 0.65 & & 1.00 & 0.00 & 0.48 \\
\hline \multicolumn{6}{|c|}{ Post-IFRS Adoption Model: Obs. 300} \\
\hline ACCRUAL(A) & 0.032 & & 0.791 & 0.00 & 0.081 \\
\hline ACCRUAL(B) & 0.030 & & 0.741 & 0.00 & 0.091 \\
\hline BSIZE & 8.36 & & 12.00 & 5.00 & 1.49 \\
\hline BIND & 4.04 & & 8.00 & 1.00 & 1.35 \\
\hline BMET & 5.43 & & 15.00 & 2.00 & 1.96 \\
\hline ACSIZE & 3.53 & & 7.00 & 3.00 & 0.73 \\
\hline ACIND & 1.76 & & 4.00 & 1.00 & 0.74 \\
\hline ACMET & 5.26 & & 12.00 & 1.00 & 1.66 \\
\hline FMOWN & 0.022 & & 0.825 & 0.000 & 0.098 \\
\hline BEQT & 0.073 & & 0.700 & 0.000 & 0.142 \\
\hline $\mathrm{AQ}$ & 0.73 & & 1.00 & 0.00 & 0.44 \\
\hline
\end{tabular}

Descriptive Statistics 
With regards to audit committee attributes, the results show that audit committee size ranges between a minimum of 3 members, a maximum of 7 members and an average of 4 members. Further, the portion of independent members in the audit committee has a minimum of I member, a maximum of 4 members with a mean of 2 independent members in audit committees. In the same line, the meetings of audit committee have a mean value of 5 meetings a year with a minimum of 1 meeting and a maximum of 17 meetings in some companies.

Audit quality has a minimum value if (0.00) which indicates companies that are audit by Non-Big-4, a maximum value of (1) which represents companies that are audited by a Big-4 with a mean of $(0.69)$ which signifies that $69 \%$ of the sample and / or the time period from 2014 to 2019 companies were audited by Big-4. In the same quest, IFRS indicates a dummy variable of 1 for post-IFRS period and 0 otherwise. Managerial ownership has a minimum ownership of $(0.000)$, maximum of $(0.86)$ and a mean of (0.067). Further, family ownership has a minimum ownership of (0.000), maximum of (0.825) and a mean of $(0.019)$.

Comparing descriptive statistics of pre and post-IFRS adoption, it is observed that the average values of discretionary accruals are higher in the post-IFRS than pre-IFRS periods. Further, the average values of audit committee meetings and size, managerial ownership and family ownership are greater in case of post-IFRS adoption however, board size, independence, meetings, audit committee independence, and IFRS have higher mean values in pre-IFRS adoption period.

\subsection{Correlation analysis}

The results in Table 3 presents an analysis of correlation between the dependent and independent variables.

Table 3

Correlation Analysis

\begin{tabular}{|c|c|c|c|c|c|c|c|c|c|c|c|c|}
\hline \multicolumn{13}{|c|}{ Collective Model: Obs.604 } \\
\hline & IFRS & BSIZE & BIND & BMET & ACSIZE & ACIND & ACMET & FOWN & FMOWN & BEQT & $\mathrm{AQ}$ & SECTOR \\
\hline IFRS & 1.00 & & & & & & & & & & & \\
\hline BSIZE & -0.07 & 1.00 & & & & & & & & & & \\
\hline BIND & -0.06 & 0.33 & 1.00 & & & & & & & & & \\
\hline BMET & -0.02 & -0.09 & 0.00 & 1.00 & & & & & & & & \\
\hline ACSIZE & -0.01 & 0.32 & 0.12 & 0.13 & 1.00 & & & & & & & \\
\hline ACIND & 0.06 & 0.01 & 0.11 & 0.10 & 0.11 & 1.00 & & & & & & \\
\hline ACMET & 0.06 & 0.03 & 0.08 & 0.23 & 0.06 & 0.04 & 1.00 & & & & & \\
\hline FOWN & 0.07 & -0.12 & -0.07 & -0.04 & -0.09 & 0.01 & -0.04 & 1.00 & & & & \\
\hline FMOWN & -0.08 & 0.18 & 0.07 & 0.09 & 0.12 & 0.13 & -0.01 & -0.06 & 1.00 & & & \\
\hline BEQT & 0.00 & 0.09 & -0.07 & -0.03 & 0.14 & 0.12 & -0.01 & 0.01 & 0.03 & 1.00 & & \\
\hline $\mathrm{AQ}$ & -0.08 & 0.22 & -0.16 & 0.05 & 0.10 & -0.07 & 0.03 & -0.06 & 0.07 & 0.07 & 1.00 & \\
\hline SECTOR & 0.00 & -0.14 & 0.10 & -0.11 & -0.18 & -0.04 & -0.06 & -0.04 & 0.10 & 0.04 & -0.10 & 1.00 \\
\hline \multicolumn{13}{|c|}{ Pre-IFRS Adoption Model: Obs. 304} \\
\hline Variables & ACCRUAL(A) & ACCRUAL(B) & ACIND & ACMET & ACSIZE & $\mathrm{AQ}$ & BEQT & BIND & BMET & BSIZE & FMOWN & \\
\hline ACCRUAL(A) & 1.00 & & & & & & & & & & & \\
\hline ACCRUAL(B) & 1.00 & 1.00 & & & & & & & & & & \\
\hline ACIND & 0.08 & 0.08 & 1.00 & & & & & & & & & \\
\hline ACMET & 0.02 & 0.02 & 0.05 & 1.00 & & & & & & & & \\
\hline ACSIZE & 0.02 & 0.02 & 0.07 & 0.00 & 1.00 & & & & & & & \\
\hline AQ & -0.06 & -0.05 & -0.08 & 0.15 & 0.11 & 1.00 & & & & & & \\
\hline BEQT & 0.04 & 0.04 & 0.07 & 0.03 & 0.15 & 0.07 & 1.00 & & & & & \\
\hline BIND & -0.04 & -0.05 & 0.11 & 0.09 & 0.12 & -0.08 & -0.09 & 1.00 & & & & \\
\hline BMET & 0.10 & 0.08 & 0.11 & 0.14 & 0.06 & 0.11 & -0.01 & -0.09 & 1.00 & & & \\
\hline BSIZE & -0.03 & -0.03 & 0.07 & 0.09 & 0.34 & 0.25 & 0.07 & 0.37 & -0.14 & 1.00 & & \\
\hline FMOWN & 0.01 & 0.01 & 0.10 & -0.06 & 0.12 & 0.07 & -0.04 & 0.08 & 0.04 & 0.21 & 1.00 & \\
\hline \multicolumn{13}{|c|}{ Post-IFRS Adoption Model: Obs. 300 } \\
\hline Variables & ACCRUAL(A) & ACCRUAL(B) & ACIND & ACMET & ACSIZE & $\mathrm{AQ}$ & BEQT & BIND & BSIZE & BMET & FMOWN & \\
\hline ACCRUAL(A) & 1.00 & & & & & & & & & & & \\
\hline ACCRUAL(B) & 0.36 & 1.00 & & & & & & & & & & \\
\hline ACIND & -0.05 & -0.08 & 1.00 & & & & & & & & & \\
\hline ACMET & 0.01 & 0.10 & 0.03 & 1.00 & & & & & & & & \\
\hline ACSIZE & 0.01 & -0.06 & 0.16 & 0.11 & 1.00 & & & & & & & \\
\hline AQ & -0.06 & -0.14 & -0.06 & -0.04 & 0.10 & 1.00 & & & & & & \\
\hline BEQT & -0.04 & -0.10 & 0.18 & -0.06 & 0.14 & 0.07 & 1.00 & & & & & \\
\hline BIND & -0.01 & 0.05 & 0.11 & 0.06 & 0.12 & -0.23 & -0.04 & 1.00 & & & & \\
\hline BSIZE & -0.01 & -0.01 & -0.06 & -0.09 & 0.29 & 0.22 & 0.12 & 0.28 & 1.00 & & & \\
\hline BMET & -0.02 & -0.05 & 0.08 & 0.24 & 0.20 & 0.03 & -0.06 & 0.07 & -0.08 & 1.00 & & \\
\hline FMOWN & -0.04 & 0.03 & 0.14 & 0.02 & 0.13 & 0.06 & 0.10 & 0.06 & 0.17 & 0.13 & 1.00 & \\
\hline
\end{tabular}

In the collective model, the results show that audit committee independence, size, audit quality, board independence and size, and IFRS have a negative correlation with the magnitude of earning managements (ACCRUAL(B)). This indicates that there is a negative relationship between audit committee independence, size, audit quality, board independence and size, and IFRS and earning management. However, ACCRUAL(A) has a positive association with all variables except for audit quality which has a negative correlation. With regards to pre and post-IFRS adoption, the results show that only audit quality, board size and independence have a negative association with both magnitudes of earning management however in the pre-IFRS adoption period, majority of the variables in post-IFRS adoption period have negative link with both magnitudes of earning management. 


\section{a. Impact of CG mechanisms on Compliance with IFRS}

The results in table (4) demonstrate the impact of corporate governance mechanisms on compliance with IFRS. The results reveal that board characteristics namely, board size (BSIZE) and board meeting (BMET) have a significant effect on compliance with IFRS at the level of $1 \%$ (P values $=0.000<0.01)$. This effect is negative which is indicated by a negative coefficient $(\beta=$ - 0.008 and -0.033 respectively). This is inconsistent with Ba-Abbad and Wan- Hussin (2011), Juhman (2017), Holland (2006), and Al-Akra et al. (2010) who found that the level of IFRS compliance is significantly influenced by board size. Further, the results regarding board meetings contradict Brick and Chidambaran, (2004) and Abdullah et al. (2015) who reported a significant association between the frequency of board meetings and the levels of disclosure requirements. However, the results show that board independence (BIND) has a significant positive effect on compliance with IFRS at the level of $1 \%(\mathrm{P}$ values $=0.000<$ 0.01 ) with a positive coefficient $(\beta=0.011)$. This is in line with (Patelli \& Prencipe, 2007; Arcay et al., 2005; Huafang \& Jianguo, 2007) who concluded that board independence increases disclosure levels. With regards to audit committee attributes, the results indicate that among audit committee attributes only audit committee independence (ACIND) exhibits a significant positive effect on compliance with IFRS at the level of $1 \%$ (P values $=0.000<0.01$ ). These results are similar to Juhman (2017), AlAkra et al., (2010) and Carcello and Neal (2003) who reported a significant link between disclosure index and AC independence. However, both audit committee size (ACSIZE) and meetings (ACMET) have insignificant effect on compliance with IFRS at any level of significance $1 \%, 5 \%$ and $10 \%$ (P values $>0.10)$. Abdullah et al. (2015) indicated that there is an insignificant association between the frequency of AC meetings and the level of mandatory disclosure requirements. The results show that foreign ownership $(\mathrm{FOWN})$ has a significant effect on compliance with IFRS at the level of $1 \%(\mathrm{P}$ values $=0.000<0.01)$. This effect is negative which is indicated by a negative coefficient $(\beta=-0.001)$. Several studies in this regard reported that there is a significant and positive relationship between IFRS compliance and foreign ownership (e.g., Bova \& Pereira, 2012; Gordon et al., 2012; Beneish et al., 2012). This could be attributed to the low level of foreign investments and limitations to foreign ownership in some companies. Further, this could be affected by a dominant family ownership in some companies. Both family (FMOWN) and board ownership (BEQ) have insignificant effect on compliance with IFRS at any level of significance 1\%, 5\% and 10\% (P values $>0.10)$. Finally, audit quality (AQ) by Big-4 exhibits insignificant effect on compliance with IFRS. This is in line with Fekete et al. (2008) and Street and Gray (2001) who reported that there is no significant impact of auditor type. Furthermore, sector as a dummy variable of 1 for manufacturing industries and 0 otherwise shows that there is insignificant difference in compliance with IFRS between manufacturing sector and service or commercial sectors. In general, the model is fit which is significant at the level of $1 \%$ ( $\mathrm{P}$ values $=0.000<0.01$ ). Further, the adjusted $\mathrm{R}^{2}$ is $13 \%$ which signifies that the predictors in the model explain $13 \%$ of the variability of compliance with IFRS.

\section{Table 4}

Impact of CG mechanisms on Compliance with IFRS (Model 1)

\begin{tabular}{|c|c|c|c|}
\hline Variable & Estimates & Variable & Estimates \\
\hline $\mathrm{C}$ & $34.673(0.879 * * *)$ & ACMET & $-0.205(0.000)$ \\
\hline BSIZE & $-3.113(-0.008 * * *)$ & FOWN & $-3.566(-0.001 * * *)$ \\
\hline BIND & $4.054(0.011 * * *)$ & FMOWN & $0.899(0.001)$ \\
\hline BMET & $-0.033 * * *(-4.495)$ & BEQT & $-0.618(-0.001)$ \\
\hline ACSIZE & $-0.707(-0.003)$ & $\mathrm{AQ}$ & $0.391(0.003)$ \\
\hline ACIND & $3.389(0.014 * * *)$ & SECTOR & $-0.782(-0.001)$ \\
\hline
\end{tabular}

R-squared $=0.158$ Adjusted R-squared $=0.127 \quad \mathrm{~F}$-statistic $=5.016(0.000)$

Note: BSIZE is board size, BIND is board independence, BMET is board meetings, ACSIZE is audit committee size, ACIND is audit committee independence, ACMET audit committee size meetings, Big-4 is audit quality, FOWN is foreign ownership, FMOWN is family ownership, MOWN is managerial ownership, and SECTOR is a dummy variable of 1 for and 0 otherwise.

\section{b. The Impact of CG mechanisms and IFRS on Earning Management}

Table 5 shows the results of regression analysis for collective model with and without a dummy variable of IFRS. The results demonstrate four columns of regression analysis, the first two columns are for collective model using discretionary accruals with firm performance magnitude (ACCRUAL(A)) and the other two columns are for collective model of discretionary accruals without firm performance magnitude (ACCRUAL(B)). Concerning ACCRUAL(A), the results show that board meeting (BMET), audit committee independence (ACIND) and meetings (ACMET) have statistically significant effect at the level of $1 \%$ on discretionary accruals. While (ACMET) indicates statistically significant negative effect on earning management, board meetings (BMET), and audit committee independence (ACIND) have statistically significant positive impact on earning management. This indicates that board meeting (BMET) and audit committee independence do not reduce earning management. Comparatively, board meeting (BMET), audit committee independence (ACIND) and meetings (ACMET) exhibit same effect in the IFRS Model ACCRUAL(A). This contradicts (Chou et al., 2013; Al-Ghamdi, 2012; Francis et al., 2012) who found that board diligence associated negatively with earning management and also inconsistent with Klein (2002) and Agrawal and Chadha (2005) who reported that independence of audit committee is a critical for lower incidence of earnings restatement. 
However, (Lin et al., 2006; Peasnell, et al., 2005; Osma \& Noguer, 2007; Siregar \& Utama, 2008; Xie et al., 2003) indicated that independent audit committees is not significantly linked with decreased earnings management levels.

Audit committee size (ACSIZE) and board size (BSIZE) exhibit statistically significant effect on earning management. Audit committee size (ACSIZE) indicate statistically significant negative $(\beta=-0.01)$ effect at the level of $10 \%$ on earning management. This is consistent with (Yang \& Krishnan, 2005; Cornett et al., 2008; Lin at al., 2006; Lin \& Hwang, 2010) who indicated that large audit committee is negatively linked with earnings management. Board size (BSIZE) exhibit statistically positive significant impact on earning management. This signifies that audit committee size associate negatively with earning management however, board size link positively with earning management. This could be attributed to that board size is higher than audit committee size which indicate that earning management is linked positively with greater board size. With regards to IFRS, the results show that there is statistically significant positive effect on earning management at the level of $1 \%$. This could be due to that earning management is measured using a performance magnitude.

Table 5

Regression Analysis of the Impact of CG and IFRS on Earning Management

\begin{tabular}{|c|c|c|c|c|}
\hline \multirow[b]{2}{*}{ Variable } & \multicolumn{2}{|c|}{ Collective model: Discretionary Accruals with firm performance } & \multicolumn{2}{|c|}{ Collective model: Discretionary Accruals without firm } \\
\hline & $\begin{array}{c}\text { Collective Model ACCRUAL(A) } \\
\text { Coefficient }\end{array}$ & $\begin{array}{l}\text { Dummy Model } \\
\text { Coefficient }\end{array}$ & $\begin{array}{c}\text { Collective Model } \\
\text { Coefficient }\end{array}$ & $\begin{array}{c}\text { Dummy Model } \\
\text { Coefficient }\end{array}$ \\
\hline \multirow[t]{2}{*}{$\mathrm{C}$} & -0.06 & $-0.08 * *$ & $0.11 * *$ & 0.06 \\
\hline & -1.18 & -2.12 & 2.63 & 1.57 \\
\hline \multirow[t]{2}{*}{ BSIZE } & 0.01 & $0.01 * * *$ & $-0.01 *$ & 0.00 \\
\hline & 0.99 & 3.28 & -1.84 & -0.79 \\
\hline \multirow[t]{2}{*}{ BIND } & -0.01 & 0.00 & $0.02 * *$ & $0.02 * *$ \\
\hline & -1.53 & -0.79 & 2.15 & 2.63 \\
\hline \multirow[t]{2}{*}{ BMET } & $0.01 * * *$ & $0.01 * * *$ & 0.00 & 0.00 \\
\hline & 4.12 & 4.03 & -0.43 & -0.06 \\
\hline \multirow[t]{2}{*}{ ACSIZE } & 0.00 & $-0.01 *$ & 0.00 & 0.00 \\
\hline & -0.45 & -1.73 & -1.09 & -0.23 \\
\hline \multirow[t]{2}{*}{ ACIND } & $0.03 * * *$ & $0.02 * * *$ & $-0.03 * * *$ & $-0.03 * * *$ \\
\hline & 2.93 & 2.95 & -7.30 & -6.99 \\
\hline \multirow[t]{2}{*}{ ACMET } & $-0.01 * * *$ & $-0.01 * * *$ & $0.00 * *$ & $0.00 * * *$ \\
\hline & -3.33 & -4.36 & -2.12 & -3.83 \\
\hline \multirow[t]{2}{*}{ FMOWN } & 0.00 & 0.00 & 0.00 & 0.00 \\
\hline & 0.08 & -0.16 & -1.09 & -0.87 \\
\hline \multirow[t]{2}{*}{ BEQT } & $0.00 * * *$ & $0.00 * * *$ & $0.00 * *$ & 0.00 \\
\hline & 3.17 & 6.03 & 2.46 & 0.71 \\
\hline \multirow[t]{2}{*}{ AQ } & -0.01 & -0.01 & $-0.04 * * *$ & $-0.03 * * *$ \\
\hline & -0.63 & -1.21 & -5.54 & -3.38 \\
\hline \multirow[t]{2}{*}{ IFRS } & & $0.03 * * *$ & & $-0.02 * *$ \\
\hline & & 6.15 & & -2.67 \\
\hline R-squared & 0.31 & 0.34 & 0.30 & 0.31 \\
\hline Adjusted R-squared & 0.16 & 0.19 & 0.15 & 0.15 \\
\hline F-statistic & 2.05 & 2.28 & 1.93 & 1.99 \\
\hline Prob(F-statistic) & 0.00 & 0.00 & 0.00 & 0.00 \\
\hline
\end{tabular}

As far as ACCRUAL(B) is concerned, the results demonstrate that audit committee independence (ACIND) and audit quality by Big-4 have statistically significant negative effect on discretionary accruals in the collective model as well as IFRS model. This is consistent with Klein (2002), Agrawal and Chadha (2005), and Bradbury et al. (2006) who found a negative association between audit committee independence and earning management. However, audit committee meetings (ACMET) and board independence (BIND) have statistically significant positive effect on earning management at the level of 5\%. This means that when discretionary accruals is used as a measure for earning management without performance magnitude, audit committee independence (ACIND) and audit quality by Big-4 are linked negatively with earning management. This is consistent with (Klein, 2002; Benkel, et al., 2006; Niu, 2006; Iqbal and Strong, 2010) who advocate that a greater portion of board independence in the board reduces the level of earnings management. Further, the results show that managerial ownership has a significant positive effect on earning management at the level of 5\%. Furthermore, IFRS exhibit statistically significant negative impact on earning management at the level of 5\% which indicates that IFRS contributed to reducing earning management (only when discretionary accruals are measured without performance magnitude). 
Table 6

Regression Analysis of the impact of CG mechanisms on earning management Pre-Post-IFRS Adoption

\begin{tabular}{|c|c|c|c|c|}
\hline \multirow[b]{2}{*}{ Variable } & ACCRUAL(A) IFRS & ACCRUAL(B) IFRS & ACCRUAL(A) GAAP & ACCRUAL(B) GAAP \\
\hline & Coefficient & Coefficient & Coefficient & Coefficient \\
\hline \multirow[t]{2}{*}{$\mathrm{C}$} & $0.25 * * *$ & $0.30^{* * *}$ & $0.15^{* * *}$ & $0.04 * * *$ \\
\hline & 3.29 & 4.50 & 4.55 & 4.34 \\
\hline \multirow[t]{2}{*}{ BSIZE } & $-0.02 * *$ & $-0.02 * * *$ & $-0.01 * * *$ & 0.00 \\
\hline & -2.80 & -3.50 & -7.09 & -1.00 \\
\hline \multirow[t]{2}{*}{ BIND } & $-0.05 * * *$ & $-0.06 * * *$ & 0.00 & $-0.00 * * *$ \\
\hline & -5.72 & -7.55 & 0.18 & 3.01 \\
\hline \multirow[t]{2}{*}{ BMET } & $0.02 * * *$ & $0.01 * * *$ & $0.00 * *$ & $0.00 * * *$ \\
\hline & 5.60 & 4.45 & -2.07 & -6.04 \\
\hline \multirow[t]{2}{*}{ ACSIZE } & 0.00 & 0.00 & 0.00 & 0.00 \\
\hline & -0.10 & 0.04 & 0.44 & -1.35 \\
\hline \multirow[t]{2}{*}{ ACIND } & 0.01 & 0.01 & $-0.03 * * *$ & $-0.01 * * *$ \\
\hline & 1.02 & 0.96 & -3.31 & -22.95 \\
\hline \multirow[t]{2}{*}{ ACMET } & $-0.02 * * *$ & $-0.02 * * *$ & 0.00 & $0.00 * * *$ \\
\hline & -4.34 & -5.01 & 1.40 & 19.29 \\
\hline \multirow[t]{2}{*}{ FMOWN } & 0.00 & 0.00 & 0.00 & $0.00 * * *$ \\
\hline & 1.17 & 1.35 & -0.54 & 13.60 \\
\hline \multirow[t]{2}{*}{ BEQ } & $0.00 * *$ & $0.00 * * *$ & $0.00 * *$ & $0.00 * * *$ \\
\hline & 2.56 & 2.91 & -2.80 & -3.10 \\
\hline \multirow[t]{2}{*}{ AQ } & $0.05 * * *$ & $0.05 * * *$ & $-0.03 * * *$ & $-0.02 * * *$ \\
\hline & 4.60 & 4.77 & -5.09 & -10.03 \\
\hline R-squared & 0.71 & 0.78 & 0.46 & 0.19 \\
\hline Adjusted R-squared & 0.55 & 0.65 & 0.15 & 0.17 \\
\hline F-statistic & 4.30 & 6.17 & 1.49 & 7.63 \\
\hline Prob(F-statistic) & 0.00 & 0.00 & 0.01 & 0.00 \\
\hline
\end{tabular}

Overall, the model fit of ACCRUAL(A) indicate that the adjusted R square in case of the collective model is $31 \%$ as compared to IFRS model which has an adjusted R square of $34 \%$. This indicates that the variables in IFRS model contribute $34 \%$ of the variability of discretionary accruals as compared to $31 \%$ in the collective model. Similarly, ACCRUAL(B) models show that the variables in IFRS model explain $31 \%$ of the variability of discretionary accruals as compared to $30 \%$ in case of the collective model. Further, $\mathrm{P}$ value of all models conducted $(\mathrm{P}$ values $=0.000<0.01)$ indicates that the models are fit. Tables 6 demonstrates the impact of corporate governance mechanisms on earning management under the two sets of accounting standards; IFRS and Saudi GAAP. Concerning IFRS, the results demonstrate that there is no difference in the impact of corporate governance mechanisms on earning management from performance magnitude discretionary accruals ACCRUAL (A) to non-performance magnitude discretionary accruals ACCRUAL (B). The results indicate that board size (BSIZE), board independence (BIND), and audit committee meetings (ACMET) have statistically significant negative influence at the level of $1 \%$ ( $P$ value $=0.000<$ 0.01 ) on both measures of earning management. Further, the results show that audit quality by Big- 4 and managerial ownership $(\mathrm{MOWN})$ have statistically significant positive effect at the level of $1 \%(\mathrm{P}$ value $=0.000<0.01)$ on discretionary accruals ACCRUAL (A) and ACCRUAL (B). This indicates that BIND, BSIZE and ACMET contribute positively to reduce earning management under IFRS but Big-4 and managerial ownership (MOWN) do not. With regards to Saudi GAAP, the results reveal that there is a slight difference in the impact of corporate governance mechanisms on earning management from performance magnitude discretionary accruals ACCRUAL (A) to non-performance magnitude discretionary accruals ACCRUAL (B). Board size (BSIZE), and audit committee independence (ACIND) exhibit statistically significant negative impact at the level of $1 \%$ (P value $=0.000<0.01)$ on discretionary accruals ACCRUAL (A). However, board meetings (BMET) and managerial ownership exhibit statistically significant positive impact at the level of 5\% (P value <0.05) on discretionary accruals ACCRUAL (A). This indicates that board meetings (BMET) and managerial ownership (MOWN) associate positively with earning management under Saudi GAAP using performance magnitude model. From the other hand, the results also reveal that board independence (BIND), audit quality by Big-4, and audit committee independence (ACIND) indicate statistically significant negative impact at the level of $1 \%$ (P value $=0.000<0.01)$ on discretionary accruals ACCRUAL (B). However, board meetings (BMET), managerial ownership (MOWN), audit committee meetings (ACMET), and family ownership (FOWN) exhibit statistically significant positive impact at the level of $1 \%(\mathrm{P}$ value $=0.000<0.01)$ on discretionary accruals using Non-performance magnitude measure ACCRUAL (B). Cheung et al. (2013) stated that FRQ in Australia is influenced by early adoption of IFRS in 2005. In this context, Bodle et al. (2016) found that IFRS predicts bankruptcy for bankrupt firms more accurately than AGAAP. Further, they reported that the switch from AGAAP to IFRS enhances the quality of financial statements contents for predicting bankruptcy. Likewise, Müller (2014) revealed an improvement in the quality of consolidated statements as a result 
of IFRS adoption, suggesting that adoption of IFRS in Europe led to better disclosure, transparency and compliance with Corporate Governance Principle of OECD. Kamil and Yu (2015) indicated that adoption of the new substantially IFRSconvergent accounting standards in China results in better FRQ addressing the effect of regulatory environments on earnings management and FRQ of firms in the pre- and post-IFRS adoption periods in both countries.

\section{c. Impact of CG mechanisms on FRQ}

The results in Table 7 demonstrate the effect of corporate governance mechanisms on financial reporting quality (FRQ). The results reveal that board size (BSIZE) has a significant effect on FRQ at the level of $10 \%$ (P values $=0.07<0.10$ ). This effect is negative which is indicated by a negative coefficient $(\beta=-0.007)$. The results also show that board meeting (BMET) has insignificant effect on FRQ (P values $<0.10$ ). However, board independence (BIND) exhibits a significant positive effect on FRQ at the level of $1 \%$ (P values $=0.000<0.01)$ with a positive coefficient $(\beta=0.009)$. Further, the results show that audit committee attributes (ACSIZE, ACIND, and ACMET) have a significant effect on FRQ at the level of $1 \%$ ( $\mathrm{P}$ values $=0.000<$ 0.01). While both audit committee size (ACSIZE) and meetings (ACMET) exhibit a negative effect ( $\beta=-0.004$ and -0.009 respectively), audit committee independence (ACIND) has a significant positive effect $(\beta=0.001)$. Furthermore, the results reveal that among ownership structure variables, only board equity (BEQ) exhibits a significant effect on FRQ at the level of $1 \%$ ( $\mathrm{P}$ values $=0.000<0.01)$ with a negative coefficient $(\beta=-0.018)$ indicating that it has a significant negative effect. However, both family and foreign ownerships have an insignificant effect.

\section{Table 7}

Impact of CG mechanisms on FRQ

\begin{tabular}{llll}
\hline Variable & Estimates & Variable & Estimates \\
\hline C & $3.895(0.122 * * *)$ & BSIZE & $-1.805(-0.007 *)$ \\
BIND & $3.350(0.009 * * *)$ & BMET & $-0.671(-0.002)$ \\
ACSIZE & $-4.016(-0.009 * * *)$ & ACIND & $4.803(0.001 * * *)$ \\
ACMET & $-2.979(-0.004 * * *)$ & FOWN & $-1.524(-0.001)$ \\
FMOWN & $0.484(0.000)$ & BEQT & $-3.795(-0.018 * * *)$ \\
AQ & $-1.269(-0.022)$ & IFRS & $3.678(0.021 * * *)$ \\
\hline
\end{tabular}

R-squared $=0.403$ Adjusted R-squared $=0.266$ S.E. of regression $=0.325$ F-statistic $=2.948(0.000)$

Note: ACCRUAL(A) is discretionary accruals measured by Kothari et al. (2005), ACCRUAL(B) is discretionary accruals measured by modified Jones model, BSIZE is board size, BIND is board independence, BMET is board meetings, ACSIZE is audit committee size, ACIND is audit committee independence, ACMET audit committee size meetings, Big-4 is audit quality, FOWN is foreign ownership, FMOWN is family ownership, MOWN is managerial ownership, and IFRS is a dummy variable of 1 for post-IFRS adoption and 0 otherwise.

Moreover, the results show that audit quality (AQ) by Big-4 has no significant effect at any level of significance $1 \%, 5 \%$ and $10 \%$ (P values 0.10$)$. Importantly, the results show that there is a significant difference of FRQ from pre-IFRS adoption to postIFRS adoption which is indicated by the estimates of IFRS. IFRS denotes a dummy variable of 0 for pre-IFRS adoption and 1 for post-IFRS adoption, the results show that IFRS is significant at the level of $1 \%$ ( $\mathrm{P}$ values $=0.000<0.01$ ) with a positive coefficient ( $\beta=0.021)$ indicating that FRQ under IFRS is better that Saudi GAAP. Cohen et al. (2004) advocated that the most important functions of corporate governance are to ensure the quality of financial reporting process. Similarly, Fairuz (2009) concluded that after controlling for political influence, weak corporate governance is associated with low FRQ. However, evidence and findings on the relationship between corporate governance mechanisms and FRQ in prior literature are mixed. While some studies in favor of the existence of a positive impact or association between corporate governance mechanisms and FRQ (Tan et al. 2013; Johl et al., 2013; Chandar et al., 2012; Zheng, 2008; Baxter, 2007; Kali \& Omri, 2011; Kardan et al., 2016) but, some studies reported a negative or no relationship between corporate governance mechanisms and FRQ (Chalaki et al., 2012; Vafeas, 2000; Ahmed et al., 2006; Bradbury et al., 2006). Overall, the model is fit which is significant at the level of $1 \%$ ( $\mathrm{P}$ values $=0.000<0.01$ ). Further, the adjusted $\mathrm{R}^{2}$ is $27 \%$ which indicates that the predictors in the model contribute $27 \%$ of the variation of FRQ.

\section{Conclusion}

current research investigates the impact of corporate governance mechanisms and IFRS on IFRS compliance, earning management and financial reporting quality. A sample of 102 Saudi listed firms form 2014 up to 2019 was used. Board size, independence, meetings, audit committee size, independence, meetings, audit quality, foreign, managerial and family ownership have been treated as corporate governance mechanisms which have been regressed along with IFRS against discretionary accruals as a measure of earning management. Two measures of discretionary accruals have been used; performance (Kothari et al (1995) and non-performance magnitude (modified Jones model) measures. Importantly, IFRS was used as a dummy variable for the period from 2017 to 2019 which considered as post-IFRS adoption and the period from 2014 to 2016 which treated as pre-IFRS adoption (Saudi GAAP). With regards to the impact of corporate governance mechanisms on compliance with IFRS, the results revealed that BSIZE and BMET have a negative significant effect however, BIND exhibited a significant positive effect on compliance with IFRS. Further, the results indicated that ACIND has a significant positive effect and FOWN 
has a significant negative effect however, all other variables; ACSIZE, ACMET, FMOWN, BEQ, and AQ are found to have insignificant effect on compliance with IFRS. The results revealed that while audit committee meetings (ACMET) have a significant negative effect on earning management using a performance magnitude (Kothari et al (1995)), board meeting (BMET), and audit committee independence (ACIND) have a significant positive effect. Comparatively, when IFRS effect is considered, board meeting (BMET), audit committee independence (ACIND) and meetings (ACMET) exhibited same effect on earning management. However, audit committee size (ACSIZE) was found to have a negative effect but, board size (BSIZE) indicated a significant positive impact on earning management. Importantly, IFRS was found to have a positive effect on earning management. This could be due to that earning management is measured using a performance magnitude. As far as nonperformance magnitude (modified Jones model) was used, the results showed that audit committee independence (ACIND) and audit quality by Big-4 have statistically significant negative effect on discretionary accruals in the collective model as well as IFRS model. However, audit committee meetings (ACMET) and board independence (BIND) have statistically significant positive effect on earning management. This means that when discretionary accruals is used as a measure for earning management without performance magnitude, audit committee independence (ACIND) and audit quality by Big-4 are linked negatively with earning management. Further, the results found that managerial ownership do not reduce the incidence of earning management because its effect is found to be positive. Furthermore, IFRS exhibit statistically significant negative impact on earning management which indicates that IFRS contributed to reducing earning management (only when discretionary accruals are measured without performance magnitude). Concerning IFRS, the results demonstrate that there is no difference in the impact of corporate governance mechanisms on earning management from performance magnitude discretionary accruals ACCRUAL (A) to non-performance magnitude discretionary accruals ACCRUAL (B). The results indicated that BIND, BSIZE and ACMET contribute positively to reduce earning management under IFRS but Big-4 and managerial ownership (MOWN) do not. With regards to Saudi GAAP, the results revealed that board meeting (BMET) and managerial ownership (MOWN) associate positively with earning management under Saudi GAAP using performance magnitude. From the other hand, the results also indicated that board independence (BIND), audit quality by Big-4, and audit committee independence (ACIND) indicate statistically significant negative impact on discretionary accruals (Non-performance magnitude model). However, board meetings (BMET), managerial ownership (MOWN), audit committee meetings (ACMET), and family ownership (FOWN) exhibit statistically significant positive impact on discretionary accruals using Non-performance magnitude measure.Concerning FRQ, the results revealed that BSIZE, ACSIZE, ACMET, and BEQ has a significant negative effect on FRQ however, BIND and ACIND exhibited a significant positive effect on FRQ. Further, the results revealed that BMET, FMOWN, FOWN, and AQ by Big-4 have insignificant effect on FRQ. Importantly, the results found that FRQ under IFRS is better that Saudi GAAP.

\section{Policy Implications Towards 2030 Vision}

Based on the findings, the present study offers multiple platforms and implications for policy makers, analysts, firms' managements, stock market authority and academicians. Essentially, with the recent adoption of IFRS by Saudi Arabia and with a dearth of research studies that address different issues after IFRS adoption, the present study introduces substantial policy implications. The results derived from the current study warn regulators especially, SOCPA about the desired effects from introducing IFRS in Saudi Arabia. Compliance with IFRS by listed companies still questionable as there is no oversight and supervisory body for financial reporting in Saudi Arabia. Accordingly, regulators and other bodies; SOCPA and Stock market authority shall constitute an oversight and supervisory body in Saudi Arabia that oversee financial reporting and impose certain rules and requirements for financial reporting. It is suggested that an oversight body which is equivalent to the Financial Reporting Council of the UK could be constituted.

An effective financial reporting system is very important for the vision on 2030. Accordingly, forming an oversight and supervisory body for financial reporting is expected to enhance the transparency and better financial reporting quality leading to attraction of foreign investors. Further, an efficient corporate governance framework is essential for 2030 vision. Hence, stock market authority shall regularly oversee the disclosure of corporate governance practices of listed firms. Auditor certificate for corporate governance requirements as per Saudi corporate governance regulations could be another possible policy action that stock market authority may impose. Further, chief executive officer or/and chief financial officer certificate on corporate governance practices shall be imposed also by stock market authority for effective governance framework in Saudi Arabia.

Another possible implication is that stock market authority and SOCPA shall direct companies for more training and IFRS capacity buildings. SOCPA has started the journey in this field however, companies board members, audit committee members, auditors and academicians shall work together for more training and IFRS education in Saudi Arabia.

\section{Limitations and directions for future research}

The present study is limited to a sample of 102 listed firms with a time frame for the period from 2014 up to 2019 . Further, the study constrained itself to a number of corporate governance mechanisms namely; board size, independence, meetings, audit committee size independence, meetings, audit quality, foreign, managerial and family ownership. Future studies may increase 
the sample, the time period, taking in consideration the other variables of corporate governance. Foreign and institutional ownership, board and audit committee expertise, board, audit committee and management remuneration and compensation are some possible streams for future research. Future research also is suggested to conduct research on integrated reporting and narrative reporting in Saudi Arabia.

\section{Acknowledgment}

The author(s) acknowledge that, the Deanship of Scientific Research at Prince Sattam Bin Abdulaziz University supported this project under the research project number 2020/02/16788.

\section{References}

Abbott, L., Parker, S. and Peters, G. (2004). Audit committee characteristics and restatements. Auditing: A Journal of Practice \& Theory, 23(1), 69-87.

Abdullah, M., Evans, L., Fraser, I., \& Tsalavoutas, I. (2015). IFRS Mandatory disclosures in Malaysia : the influence of family control and the value relevance of compliance levels. Accounting Forum, 39(4), 328-348.

Abeysekera, I. (2010). The influence of board size on intellectual capital disclosure by Kenyan listed firms. Journal of Intellectual Capital, 11(4), 504-518.

Ahmed, A. S., \& Duellman, S. (2006). Evidence on the role of accounting conservatism in corporate governance. Journal of Accounting and Economics, 43(2-3), 411-437.

Agrawal, A., \& Chadha, S. (2005). Corporate governnace and accounting scandels. The Journal of Law and Economics, XLVIII(October), 371-406.

Akhtaruddin, M., \& Haron, H. (2010). Board ownership, audit committees' effectiveness and corporate voluntary disclosures. Asian Review of Accounting, 18(1), 68-82.

Akhtaruddin, M., Hossain, M. A., Hossain, M., \& Yao, L. (2009). Corporate governance and voluntary disclosure in corporate annual reports of Malaysian listed firms. Journal of Applied Management Accounting Research, 7(1), 1-19.

Al-Akra, M., Eddie, I. A., \& Ali, M. J. (2010). The influence of the introduction of accounting disclosure regulation on mandatory disclosure compliance: Evidence from Jordan. The British Accounting Review, 42(3), $170-186$.

Al-bassam, W. M., Ntim, C. G., Opong, K. K., \& Downs, Y. (2018). Corporate boards and ownership structure as antecedents of corporate governance disclosure in Saudi Arabian publicly listed corporations. Business \& Society, SAGE, 57 (2), $335-$ 377.

Al-bassam, W. M., Ntim, C. G., Opong, K. K., \& Downs, Y. (2015). Corporate Boards and Ownership Structure as Antecedents of Corporate Governance Disclosure in Saudi Arabian Publicly Listed Corporations. Business \& Society, 1-43.

Al-Janadi, Y., Rahman, R. A., \& Alazzani, A. (2016). Does government ownership affect corporate governance and corporate disclosure? Evidence from Saudi Arabia. Managerial Auditing Journal, 31(8/9), 871-890.

Al-matari, Y. A., Al-Swidi, A. K., \& Fadzil, F. H. B. (2012). Corporate Governance and Performance of Saudi Arabia Listed Companies. British Journal of Arts and Social Sciences, 9(I), 1-30.

Al-matari, Y. A., \& Al-matari, E. M. (2012). Board of directors, audit committee characteristics and performance of Saudi Arabia listed companies. International Review of Management and Marketing, 2(4), 241-251.

Al-Shaer, H., Salama, A., \& Toms, S. (2017). Audit committees and financial reporting quality: evidence from UK environmental accounting disclosures. Journal of Applied Accounting Research, 18(1), 2-22.

Al-Shiab, M., (2003). 'Financial consequences of IAS adoption: the case of Jordan', PhD thesis, University of Newcastle UponTyne, UK.

Al-Thuneibat, A. A., Al-Angari, H. A., \& Alssad, S. A. (2016). The effect of corporate governance mechanisms on earnings management: evidence from Saudi Arabia. Review of International Business and Strategy, 26(1), 1-45.

Alajlan, W. (2015). Ownership patterns and the Saudi market. Corporate Governance,9(2) 161-186.

Alghamdi, S. A. (2012). Investigation into Earnings Management Practices and the Role of Corporate Governance and External Audit in Emerging Markets: Empirical Evidence from Saudi Listed Companies. (Doctoral dissertation, Durham University)

AlQahtani, S. A. M. (2014). Top Management Teams' Influence on Strategic Decision Making and Firms' Outcome in the Case of Saudi Arabia's Private Sector.(Doctoral dissertation, University of Southampton).

Alshetwi, M. (2016). The Association between Audit Committee Members ' Multiple Directorship, Ownership and Earnings Management in Saudi Arabia. International Business Research, 9(10), 33-45.

Alsultan, A. S. (2017). Audit Quality, IPOs and Earnings Management : Evidence from Saudi Arabia. (Doctoral dissertation, University of Portsmouth)

Altuwaijri, B., \& Kalyanaraman, L. (2016). Is ' Excess' Board Independence Good for Firm Performance? An Empirical Investigation of Non-financial Listed Firms in Saudi Arabia. International Journal of Financial Research, 7(2), 84-92.

Alzahrani, Y. A. (2013). The Corporate Governance in Saudi Listed Companies. International Journal of Humanities and Management Sciences (IJHMS), 1(4), 9-11.

Alzahrani, A. M. (2014). Corporate governance and firm performance: a study of public listed companies in the Kingdom of 
Saudi Arabia. (Doctoral dissertation, Universiti Utara Malaysia).

Alkahtani, F. S. (2013). Current practices of Saudi corporate governance: a case for reform. (Doctoral dissertation, Brunel University)

Arcay, R., \& Vazquez, F. (2005). Corporate characteristics, governance rules and the extent of voluntary disclosure in Spain. Advances in Accounting, 21, 299-331.

Ba-Abbad, K. M., \& Wan-Hussin, W. N. (2011). Internal corporate governance mechanisms and the level of compliance with mandatory IFRSs disclosure requirements. In In 1st International Conference on Accounting, Business and Economics (ICABEC), Kuala Terengganu, Terengganu, November (pp. 1-2).

Baatour, K., Othman, H. Ben, \& Hussainey, K. (2017). The effect of multiple directorships on real and accrual-based earnings management : evidence from Saudi listed firms. Accounting Research Journal, 30 (4), 395-412.

Bathula, H. (2008). Board Characteristics and Firm Performance: Evidence from New Zealand. (Doctoral dissertation, Auckland University of Technology, New Zealand).

Baxter, P. J. (2007). Audit committees and financial reporting quality. (Doctoral dissertation, University of Southern Queensland)

Baxter, P., \& Cotter, J. (2009). Audit committees and earnings quality. Accounting \& Finance, 49(2), 267-290.

Beneish, M. D., Miller, B. P., \& Yohn, T. L. (2012). The impact of financial reporting on equity versus debt markets: Macroeconomic evidence from mandatory IFRS adoption.

Benkel, M., Mather, P., \& Ramsay, A. (2006). The association between corporate governance and earnings management: the role of independent directors. Corporate Ownership \& Control, 4(3), 65-75.

Biddle, G. C., Hilary, G., \& Verdi, R. S. (2009). How does financial reporting quality relate to investment efficiency? Journal of Accounting and Economics, 48(2-3), 112-131.

Bodle, K. A., Cybinski, P. J., \& Monem, R. (2016). Effect of IFRS adoption on financial reporting quality Evidence from bankruptcy prediction. Accounting Research Journal, 29(3), 292-312.

Botti, L., Boubaker, S., Hamrouni, A., \& Solonandrasana, B. (2013). Corporate governance efficiency and internet financial reporting quality. Review of Accounting and Finance, 13(1), 43-64.

Bova, F. and Pereira, R. (2012), The determinants and consequences of heterogeneous IFRS compliance levels following mandatory IFRS adoption: evidence from a developing country, Journal of International Accounting Research. 11(1), 83111.

Bradbury, M., Mak, Y., \& Tan, S. (2006). Board characteristics, audit committee characteristics and abnormal accruals. Pacific Accounting Review, 18(2), 47-68.

Brick, I. E., \& Chidambaran, N. K. (2010). Board meetings, committee structure, and firm value. Journal of Corporate Finance, 16(4), 533-553.

Brown, P., Beekes, W., \& Verhoeven, P. (2011). Corporate governance, accounting and finance: a review. Accounting \& Finance, 51(1), 96-172.

Call, A. C., Campbell, J. L., Dhaliwal, D. S., \& Moon, J. R. (2017). Employee quality and financial reporting outcomes. Journal of Accounting and Economics, 64, 123-149.

Carcello, J. V., \& Neal, T. L. (2003). Audit committee characteristics and auditor dismissals following "new" going- concern reports. The Accounting Review, 78(1), 95-117.

Chalaki, P., Didar, H., \& Riahinezhad, M. (2012). Corporate Governance Attributes and Financial Reporting Quality : Empirical Evidence from Iran. International Journal of Business and Social Science, 3(15), 223-229.

Chandar, N., Chang, H., \& Zheng, X. (2012). Does overlapping membership on audit and compensation committees improve a firm 's financial reporting quality? Review of Accounting and Finance, 11(2), 141-165.

Chobpichien, J., Haron, H., \& Ibrahim, D. (2008). The quality of board of directors, ownership structure and level of voluntary disclosure of listed companies in Thailand. Euro Asia Journal of Management, 3(17), 3-39.

Chou, H., Chung, H., \& Yin, X. (2013). Attendance of Board Meetings and Company Performance : Evidence from Taiwan. Journal of Banking Finance, 37(11).

Cheung, E., Evans, E., \& Wright, S. (2013). An historical review of quality in financial reporting in Australia. Pacific Accounting Review, 22(2), 147-169.

Cohen, J., Krishnamorthy, G., \& Wright, A. (2004). The corporate governance mosaic and financial reporting quality. Journal of Accounting Literature, 23, 87-152.

Cornett, M. M., McNutt, J. J., \& Tehranian, H. (2009). Corporate governance and earnings management at large U.S. bank holding companies. Journal of Corporate Finance, 15(4), 412-430.

Cornett, M. M., Marcus, A. J., \& Tehranian, H. (2008). Corporate governance and pay-for-performance: the impact of earnings management. Journal of Financial Economics, 87(2), 357-73.

Darweesh, M. S. (2015). Correlations Between Corporate Governance, Financial Performance, and Market Value. (Doctoral dissertations, Walden University,U.K).

Davidson, R., Goodwin-Stewart, J., \& Kent, P. (2005). Internal governance structures and earnings management. Accounting \& Finance, 45(2), 241-267.

Dechow, P. M., and I. D. Dichev. 2002. The Quality of Accruals and Earnings: The Role of Accrual Estimation Errors. The 
Accounting Review, 77(4), 35-59.

Dechow, P. M., and R. G. Sloan. 1995. Detecting Earnings Management. The Accounting Review, 70(2), $193-225$.

DeFond, M., Hu, X., Hung, M., \& Li., S. (2011). The impact of mandatory IFRS adoption on foreign mutual fund ownership: the role of comparability. Journal of Accounting and Economics, 51(2), 240-258.

Ditropoulos, P., \& Asteriou, D. (2010). The effect of board composition on the informativeness and quality of annual earnings: Empirical evidence from Greece. Research in International Business and Finance, 24(2), 190-205.

Dong, N., Wang, F., Zhang, J., \& Zhou, J. (2020). Ownership structure and real earnings management : Evidence from China. Journal of Accounting and Public Policy, 39(3), May-June 2020, 106733.

Ebrahim, A. (2007). Earnings management and board activity: An additional evidence. Review of Accounting \& Finance, 6(1), $42-58$.

Fairuz, M. (2009). Political influence, corporate governance and financial reporting quality: evidence from companies in Malaysia. (Doctoral dissertation, Massey University).

Farber, D. (2005). Restoring trust after fraud: does corporate governance matter? The Accounting Review, 80(2), 539-561.

Fekete, S., Matis, D., \& Lukács, J. (2008). Factors Influencing the Extent of Corporate Compliance with IFRS . The Case of Hungarian Listed Companies . Annales Universitatis Apulensis Series Oeconomica, I(10).

Francis, B., Hasan, I., \& Wu, Q. (2012). Do corporate boards affect firm performance ? New evidence from the financial crisis. Bank of Finland Research Discussion Papers No. 11/2012, 1-58.

Ghabayen, M. A. (2012). Board Characteristics and Firm Performance: Case of Saudi Arabia. International Journal of Accounting and Financial Reporting, 2(2), 168-200.

García Lara, J. M., García Osma, B., \& Penalva, F. (2009). Accounting conservatism and corporate governance. Review of Accounting Studies, 14(1), 161-201.

Góis, C. G. (2009). Financial reporting quality and corporate governance: the Portuguese companies evidence. In Proceedings of the 32nd Annual Congress European Accounting Association, (August), 1-25.

Gomariz, M. F. C., \& Ballesta, J. P. S. (2013). Financial reporting quality , debt maturity and investment efficiency. Journal of Banking \& Finance40(March), 494-506.

Gordon, L. A., Loeb, M. P., \& Zhu, W. (2012). The impact of IFRS adoption on foreign direct investment. Journal of Accounting and Public Policy, 31(4), 374-398.

Habbash, M. (2019). The Role of Corporate Governance Regulations in Constraining Earnings Management Practice in Saudi Arabia. In Azid, T., Alnodel, A.A. and Qureshi, M.A. (Ed.) Research in Corporate and Shari'ah Governance in the Muslim World: Theory and Practice, Emerald Publishing Limited (pp. 127-140).

Habbash, M. (2010). The effectiveness of corporate governance and external audit on constraining earnings management practice in the UK. (Doctoral dissertation, Durham University).

Habbash, M., \& Alghamdi, S. (2016). Audit quality and earnings management in less developed economies : the case of Saudi Arabia. Journal of Management \& Governance Springer Science+Business Media New, 21, 351-373 (2017).

Habbash, M., \& Alghamdi, S. (2015). The perception of earnings management motivations in Saudi public firms. Journal of Accounting in Emerging Economies, 5(1),122-147.

Hamberg, M., Mavruk, T., \& Sjögren, S. (2013) Investment allocation decisions, home bias and the mandatory IFRS adoption. Journal of International Money and Finance, 36(September), 107-130.

Hill, B., Lunn, M., Morrison, W., Mueller, J., \& Robertson, C. (2015). Saudi Arabia : An Overview of Executive Compensation , Board Structure, and Sustainability. Drake Management Review, 4(1), 20-33.

Holland, R. (2006). (De) Rationalizing the irrational: discourse as culture/ ideology. Critical Discourse Studies, 3(1), $37-59$.

Huafang, X., \& Jianguo, Y. (2007). Ownership structure, board composition and corporate voluntary disclosure: Evidence from listed companies in China. Managerial Auditing Journal, 22(6), 604-619.

Iqbal, A., \& Strong, N. (2010). The efffect of corporate governance on earning management around UK rights issues. International Journal of Managerial Finance, 6(3), 168-189.

Johl, S. K., Johl, S. K., Subramaniam, N., \& Cooper, B. (2013). Internal audit function , board quality and financial reporting quality : evidence from Malaysia. Managerial Auditing Journal, 28(9), 780-814.

Jones, J. J. (1991). Earnings Management During Import Relief Investigations. Journal of Accounting Research, 29(2), 193228.

Juhman, O. (2017). Corporate Governance and the Level of Bahraini Corporate Compliance with IFRS Disclosure. Journal of Applied Accounting Research, 18(1). 22-41.

Kardan, B., Salehi, M., \& Abdollahi, R. (2016). The relationship between the outside financing and the quality of financial reporting : evidence from Iran. Journal of Asia Business Studies, 10(1), 20-40.

Kamil, M. N., \& Yu, O. Y. (2015). Does Regulatory Environment affect Earnings Management in Transitional Economies? An Empirical Examination of the Financial Reporting Quality of Cross-Listed Firms of China and Hong Kong. Neo-Transitional Economics, 16, 245-276.

Karim, A., \& Ahmed, J. (2005). Determinants of IAS disclosure compliance in developing countries, evidence from exchangelisted companies in Bangladesh. Working Paper No. 21, Victoria University of Wellington, Wellington. 
Klai, N., \& Omri, A. (2011). Corporate Governance and Financial Reporting Quality : The Case of Tunisian Firms. International Business Research, 4(1), 158-166.

Klein, A. (2002). Audit committee, board of director characteristics and earnings management. Journal of Accounting and Economics, (33)3, 375-400.

Koh, P. S., Laplante, S. K., \& Tong, Y. H. (2007). Accountability and value enhancement roles of corporate governance. Accounting and Finance, 47(2), 305-333.

Kothari, S. P., A. J. Leone, and C. E. Wasley. 2005. Performance matched discretionary accrual measures. Journal of Accounting and Economics, 39 (1), 163-197.

Lee, E., Walker, M., \& Zeng, C. (2013). Does IFRS Convergence Affect Financial Reporting Quality in China? In Association of Chartered Certified Accountants \& Certified Accountants Educational Trust (London).

Li, B., Zheng, W., \& Ma, C. (2019). Do bullet trains affect earnings management? Evidence from China. Finance Research Letters, 31(December), 2-4.

Li, Q., \& Wang, T. (2010). Financial reporting quality and corporate investment efficiency: Chinese experience. Nankai Business Review International, 1(2), 197-213.

Lin, J. W., \& Hwang, M. I. (2010). Audit quality, corporate governance, and earnings management: A meta-analysis. International Journal of Auditing, 14(1), 57-77.

Lin, J. W., Li, J. ., \& Yang, J. S. (2006). The effect of audit committee performance on earnings quality. Managerial Auditing Journal, 21(6), 921-933.

PricewaterhouseCoopers LLP. (2014). IFRS adoption by country.

Mambondiani, L. S. (2011). Corporate governance of banks : evidence from zimbabwe's banking sector. (Doctoral Dissertation, The University of Manchester, Manchester, UK)

Manduca, P. (2016). Getting it right Adoption of IFRS in Saudi Arabia. In Deloitte.

McNichols, M., (2002). Discussion of 'The quality of accruals and earnings: the role of accrual estimation errors.'. The Accounting Review 77 (ss-1.), 61-69.

Modum, U., Ugwoke, R. O., \& Onyeanu, E. O. (2013). Content analysis of effect of board size, composition, frequency of meetings and regulrity in attendance at meetings on financial performance of quoted companies on the Nigerian Stock Exchange 2006-2012. European Journal of Business and Management, 5(26), 186-200.

Mohamad, W., \& Sulong, Z. (2010). Corporate governance mechanisms and extent of disclosure: Evidence from listed companies in Malaysia. International Business Research, 3(4), 216-228.

Nelson, J., Gallery, G., \& Percy, M. (2010). The role of corporate governance in mitigating the selective disclosure of executive stock option information. Accounting and Finance, 50(3), 685-717.

Müller, V.-O. (2014). The Impact of IFRS Adoption on the Quality of Consolidated Financial Reporting. Procedia - Social and Behavioral Sciences, 109(2014), 976-982.

Niu, F. F. (2006). Corporate governance and the quality of accounting earnings : a Canadian perspective. International Journal of Managerial Finance, 2(4), 302-327.

Ntim, C. G., \& Osei, K. A. (2011). The Impact of Corporate Board Meetings on Corporate Performance in South Africa. African Review of Economics and Finance, 2(2), 83-103.

Onuorah, Chi-chi, A., \& Friday, I. O. (2016). Corporate Governance and Financial Reporting Quality in Selected Nigerian Company. International Journal of Management Science and Business Administration, 2(3), 7-16.

Oraby, S. A. (2017). The Impact of Earnings Management Strategies on Accounting Information Relevance. International Journal of Business and Social Science, 8(4), 125-135.

Osma, B. G. ., \& Noguer, B. G. A. (2007). The effect of the board composition and its monitoring committees on earnings management: Evidence from Spain. Corporate Governance: An International Review, 15(6), 1413-1428.

Owusu-Ansah, S., \& Yeoh, J. (2005). The effect of legislation on corporate disclosure practices. Abacus, 41(1), 92-109.

Patelli, L., \& Prencipe, A. (2007). The relationship between voluntary disclosure and independent directors in the presence of a dominant shareholder. European Accounting Review, 16(1), 5 - 33.

Peasnell, P., Pope, P., \& Young, S. (2005). Board monitoring and earnings management: Do outside director's influence abnormal accruals? Journal of Business Finance and Accounting, 32(7-8), 1311-1346.

Petra, S. (2007). The effects of corporate governance on the informativeness of earnings. Economics of Governance, 8(2007), $129-152$.

Rahman, R. A., \& Omar, N. B. (2013). Corporate governance mechanisms and voluntary disclosure in Saudi Arabia. Research Journal of Finance and Accounting, 4(4), 25-35.

Ramady, M. A. (2012). The GCC Economies: Stepping Up To Future Challenges.

Ruth, H., Emma, G. \& Marti'nez, I. (2011). Corporate Governance and Intellectual Capital Disclosure. Journal of business ethics, 100(3), 483-495.

Samaha, K., Dahawy, K., Hussainey, K., \& Stapleton, P. (2012). The extent of corporate governance disclosure and its determinants in a developing market: The case of Egypt. Advances in Accounting, 28(1), 168-178.

Shehata, N. F. (2015). Development of corporate governance codes in the GCC : an overview. Corporate Governance, 15(3), $315-338$. 
Silva, M., Lima, L., \& Craig, R. (2012). Factors influencing the preparedness of large unlisted companies to implement adapted International Financial Reporting Standards in Portugal. Journal of International Accounting, Auditing and Taxation, 21(2), 169-184.

Siregar, S. V., \& Utama, S. (2008). Type of earnings management and the effect of ownership structure, firm size, and corporategovernance practices: Evidence from Indonesia. The International Journal of Accounting, 43(1), 1-27.

Song, J., \& Windram, B. (2004). Benchmarking audit committee effectiveness in financial reporting. International Journal ofAuditing, 8(3), 195-205.

Srithanpong, T. (2013). Foreign ownership and firm performance in the Thai construction industry. International Proceedings of Economics Development \& Research, 55, 72-89.

Street, D. L., \& Gray, S. J. (2002). Factors influencing the extent of corporate compliance with International Accounting Standards: Summary of a research monograph. Journal of International Accounting, Auditing and Taxation, 11(1), 51-76.

Street, D., \& Gray, S. (2001). Observance of International Accounting Standards: Factors explaining non-compliance. Association of Chartered Certified Accountants (ACCA) Research Report, No. 74, London, UK.

Tan, L., Xue, Y., \& Yu, Y. (2013). Does stronger corporate governance improve financial reporting quality? Evidence from a regression discontinuity analysis of shareholder-sponsored governance proposals. Jurnal Internasional, 1-34.

Vafeas, N. (2000). Board structure and the informativeness of earnings. Journal of Accounting and Public Policy, 19(2), 139160.

Xie, B., Davidson, W., \& DaDalt, P. (2003). Earnings management and corporate governance: The roles of the board and the audit committee. Journal of Corporate Finance, 9(3), 295-317.

Yang, J. S., \& Krishnan, J. (2005). Audit committee quarterly earnings management. International Journal of Auditing, 9(3), 1-219.

Yasser, Q. R., Mamun, A. A., \& Ahmed, I. (2016). Quality of Financial Reporting in the Asia-Pacific Region : The Influence of Ownership Composition. Review of International Business and Strategy, 26 (4), 543-560.

Yuen, D. C. Y., Zhang, X., \& Liu, M.; Lu, C. (2009). A case study of voluntary disclosure by Chinese enterprises. Asian Journal of Finance \& Accounting, 1(2), $118-145$.

Zheng, X. (2008). An Empirical Analysis of the Relationship between Audit Committee Multiple Directorships and Financial Reporting Quality. Doctoral dissertation, Drexel University, U.K.

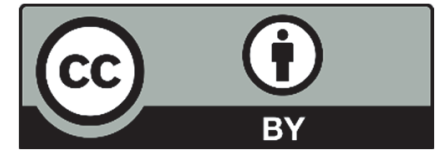

(C) 2020 by the authors; licensee Growing Science, Canada. This is an open access article distributed under the terms and conditions of the Creative Commons Attribution (CC-BY) license (http://creativecommons.org/licenses/by/4.0/). 